\title{
Structure of the phenotypic variability of fruit and seeds of Dipteryx alata vogel (Fabaceae)
}

\author{
Elias Emanuel Silva Motaํㅜ, Carolina Ribeiro Diniz Boaventura Novaes ${ }^{2}$, \\ Luciana Borges e Silva ${ }^{3}$, Lázaro José Chaves ${ }^{4}$ \\ Abstract - Dipteryx alata Vogel ("baru tree") is a fruit species native to the Brazilian Cerrado and \\ presents a multiplicity of uses, constituting a priority species for domestication and cultivation \\ studies. The objective of the current study was to characterize fruit and seeds of $D$. alata from \\ several regions of the Brazilian Cerrado biome to support strategies for ex situ conservation and \\ utilization of the genetic variability of the species. Fruits were collected from 25 subpopulations, \\ sampling six mother plants per subpopulation, with collection of at least 25 fruits per plant. The \\ physical trait data of the fruits and seeds were submitted to descriptive analysis, analysis of variance \\ and correlation among traits. There was significant variation for all traits among subpopulations and \\ among individuals within subpopulations. The highest proportion of variability was observed among \\ individuals within subpopulations. The phenotypic differentiation among subpopulations was higher \\ for fruit traits compared to seed traits. The correlation analysis showed the existence of significant \\ correlations for most of the traits pairs in the different hierarchical levels. It was concluded that $D$. \\ alata presents phenotypic variability to support germplasm collection programs and formation of \\ base populations for breeding programs, recommending the sampling in several locations to ensure \\ an adequate representativeness of the phenotypic variability. \\ Index Terms: Fruit and seed morphology, phenotypic variation, baru tree, Cerrado, genetic resources.

\section{Estrutura da variabilidade fenotípica de caracteres de frutos e sementes de baruzeiro (Dipteryx alata Vog.)}

Corresponding author: elias-emanuel@hotmail.com

Received: January 17, 2019 Accepted: June 15, 2020

Copyright: All the contents of this journal, except where otherwise noted, is licensed under a Creative Commons Attribution License.
Resumo - Dipteryx alata Vog. (barueiro) é uma espécie frutífera nativa do Cerrado brasileiro e apresenta multiplicidade de usos, constituindo-se em espécie prioritária para estudos de domesticação e cultivo. O presente trabalho teve como objetivo caracterizar fisicamente frutos e sementes de barueiro provenientes de coleta de germoplasma em diferentes regiões do Cerrado, visando à conservação ex situ e a utilização da variabilidade genética da espécie. Foram coletados frutos de plantas de 25 subpopulações, em seis estados, amostrando seis matrizes por subpopulação, com coleta de, pelo menos, 25 frutos por matriz. Os dados de caracterização física dos frutos e das sementes foram submetidos à análise descritiva, análise de variância e correlação entre caracteres. Houve variação significativa para todas as variáveis avaliadas entre subpopulações e entre matrizes dentro de subpopulações. A maior proporção da variabilidade foi observada entre matrizes dentro de subpopulações. A divergência fenotípica entre subpopulações foi maior para caracteres de frutos em comparação com caracteres de sementes. A análise de correlação demonstrou a existência de correlações significativas para a maioria dos pares de caracteres avaliados nos diferentes níveis hierárquicos. Conclui-se que D. alata possui variabilidade fenotípica para sustentar programas de coleta de germoplasma e formação de populações-base para programas de melhoramento genético, recomendando-se a coleta em múltiplas procedências para assegurar uma adequada representatividade da variabilidade fenotípica.

Termos para indexação: Morfologia de frutos e sementes, variação fenotípica, baru, Cerrado, recursos genéticos.

Biologist, Dr., Professor in the Agronomy course, Evangelical College of Goianésia - FACEG, Goianésia, Goiás, Brasil. E-mail: elias-emanuel@ hotmail.com ORCID 0000-0003-2572-3400

${ }^{2}$ Biologist, Dr., Postdoctoral, Federal University of Lavras, UFLA, Lavras, Minas Gerais, Brasil. E-mail: cboaventura@gmail.com ORCID 00000003-3674-4813

${ }^{3}$ Agronomist, Dr., Professor of the Fruit Growing Setor, Federal Institute of Goiás, Campus Ceres, Goiás, Brasil. E-mail: luciana.silva@ifgoiano. edu.br ORCID 0000-0002-7206-7488

${ }^{4}$ Agronomist,Dr., Professor of the Plant Breeding Sector, UFG, Goiânia, Goiás, Brasil. E-mail: lchaves@agro.ufg.br ORCID 0000-0002-46789014 


\section{Introduction}

Brazilian Cerrado is the second largest biome in South America, occupying 23\% of the Brazilian territory, surpassed in area only by the Amazon biome. It presents a vegetation with several phytophysiognomies, and has the richest flora among the savannas of the world (MYERS et al., 2000; KLINK and MACHADO, 2005; MENDONÇA et al., 2008). It is considered one of the 35 hotspots in the world for conservation purposes, due to its biological diversity, endemism and threat from human occupation (MYERS et al., 2000; MITTERMEIER et al., 2011). Studies indicate that about $61 \%$ of this biome is still covered by native vegetation in a relatively intact state, however, on a highly asymmetric basis. The northern part has $90 \%$ of its natural physiognomies and the southern part only 15\% (SANO et al., 2010a).

The native fruit trees of Cerrado, from different genera and families, constitute an important source of food for animals and produce fruits of interest for both fresh food and industrialization. There is a potential and growing market for native fruit, but little explored by farmers (MING et al., 2000). In contrast, Brazilian socio-biodiversity product chains have been presented as solutions to threats to Brazilian biomes (DINIZ and CERDAN, 2017). Native fruits have been used in school feeding programs, food acquisition programs and in a policy of guaranteeing minimum prices for products, in recognition of their socio-environmental and nutritional importance (MESSIAS and CAMARGO, 2016; BRASIL, 2018). In this perspective, interest in these fruits has reached several sectors of society, among which stand out farmers, housewives, industries, traders, research and technical assistance institutions, cooperatives, university centers, health, education and health agencies, among others (PEREIRA and PASQUALETO, 2011). The concentration of efforts on the genetic conservation of fruit species must be established based on the genetic variation among and within populations, seeking to collect and preserve the maximum genetic variability of the species (PAIVA et al., 2003).

Dipteryx alata Vogel - Fabaceae (baru tree) is a tree legume, which occurs in several Cerrado phytophysiognomies (LORENZI, 1998). Its wide geographical distribution is indicative of the possibility of the species presenting high levels of genetic diversity, thus conferring the capacity to occupy different habitats (KAGEYAMA et al., 2003). This species has a multiplicity of uses, constituting a key species for studies of domestication and cultivation. It is used as food by local human population and some groups of animals, as bats, monkeys, rodents, birds, ants and domesticated cattle. The pulp (mesocarp) and seed are edible and have a pleasant taste. The toasted seed (baru nut) has high nutritional value, being the main product and achieving high values in the specialized market. The oil extracted from the seed is used in food and pharmaceutical industry. In pastures, it is beneficial due to its use as a shelter for cattle, the energy and nutritional value of the fruits and the maintenance of the forage quality. The tree presents high density, compact wood, with high durability, high resistance to rot and is indicated for piles, civil construction, landscaping and recovery of degraded areas (FERREIRA, 1980; ALMEIDA, 1998; SANO et al., 2004).

It is important to sample fruits and seeds from different geographical locations to characterize a fruit species morphologically, which allows verifying the phenotypic differences determined by genetic and environmental variations. Therefore, even in the case of only one species, in each location the seeds are subject to environmental variations that highlight certain aspects of their genetic composition, that is, by studying different origins, it can capture various expressions of the genotype, allowed by the appropriate environmental conditions (BOTEZELLI et al., 2000).

Despite still limited, studies have been carried out to characterize the variability of quantitative traits in $D$. alata, such as that of Melhem (1974), who worked with the characterization and physiology of baru tree; Sano et al. (1999), who sampled fruits of 57 matrices from the states of Goiás and Minas Gerais; Corrêa et al. (2000), who conducted a study sampling fruits of 150 plants from three regions of the state of Goiás and Corrêa et al. (2008) who carried out a study of fruit morphological traits from 36 mother plants from different municipalities in the state of Goiás, with the evaluation of 20 fruits per plant. In general, these studies were performed based on samples from a little numbers of populations and in restricted geographical areas. Some studies with molecular markers show a pattern of genetic variability with low polymorphism compared to other species from the Cerrado biome, moderate to high diversity among subpopulations, a decreasing pattern of intrapopulational variability from the southwest to the rest of the biome, possible effect of landscape changes on the structure of genetic variability and a certain tolerance to future climate changes (SOARES et al., 2008a; SOARES et al., 2008b; MELO et al., 2011; DINIZ-FILHO et al., 2012a; DINIZ-FILHO et al., 2012b; COLLEVATTI et al., 2013; TELLES et al., 2014; SOARES et al., 2015; GUIMARÃES et al., 2019a; GUIMARÃES et al., 2019b).

The current study aimed to access information on the patterns of phenotypic variability for $D$. alata fruit and seed traits from wide sampling in the Cerrado biome, in order to support conservation strategies and use of the species genetic variability. 


\section{Material and methods}

The collection of material for this study was carried out in 25 subpopulations, in the following Brazilian States: Goiás (GO), Tocantins (TO), Mato Grosso (MT), Mato Grosso do Sul (MS), Minas Gerais (MG) and São Paulo (SP) (Figure 1). Six mother plants were randomly sampled from each subpopulation from those with sufficient production, with collection of at least 25 undamaged fruits per plant. A random sample of five fruits per plant was used for physical characterization. After obtaining the data of the fruits, they were opened for the evaluation of the seeds characters, maintaining the individual seed identification.
Fruit collection was carried out respecting their point of physiological maturation, which corresponds to the point at where they easily detach themselves from branches or those that are already in the soil under the canopy of plants. Once harvested, the fruits were packaged in plastic mesh bags, labeled and identified with the subpopulation and plant numbers, and then transported to the laboratory at the Federal University of Goiás, in Goiânia. Each mother plant was geo-referenced using a GPS receiver and each subpopulation was plotted in the map using its central geographic coordinates (Figure 1).

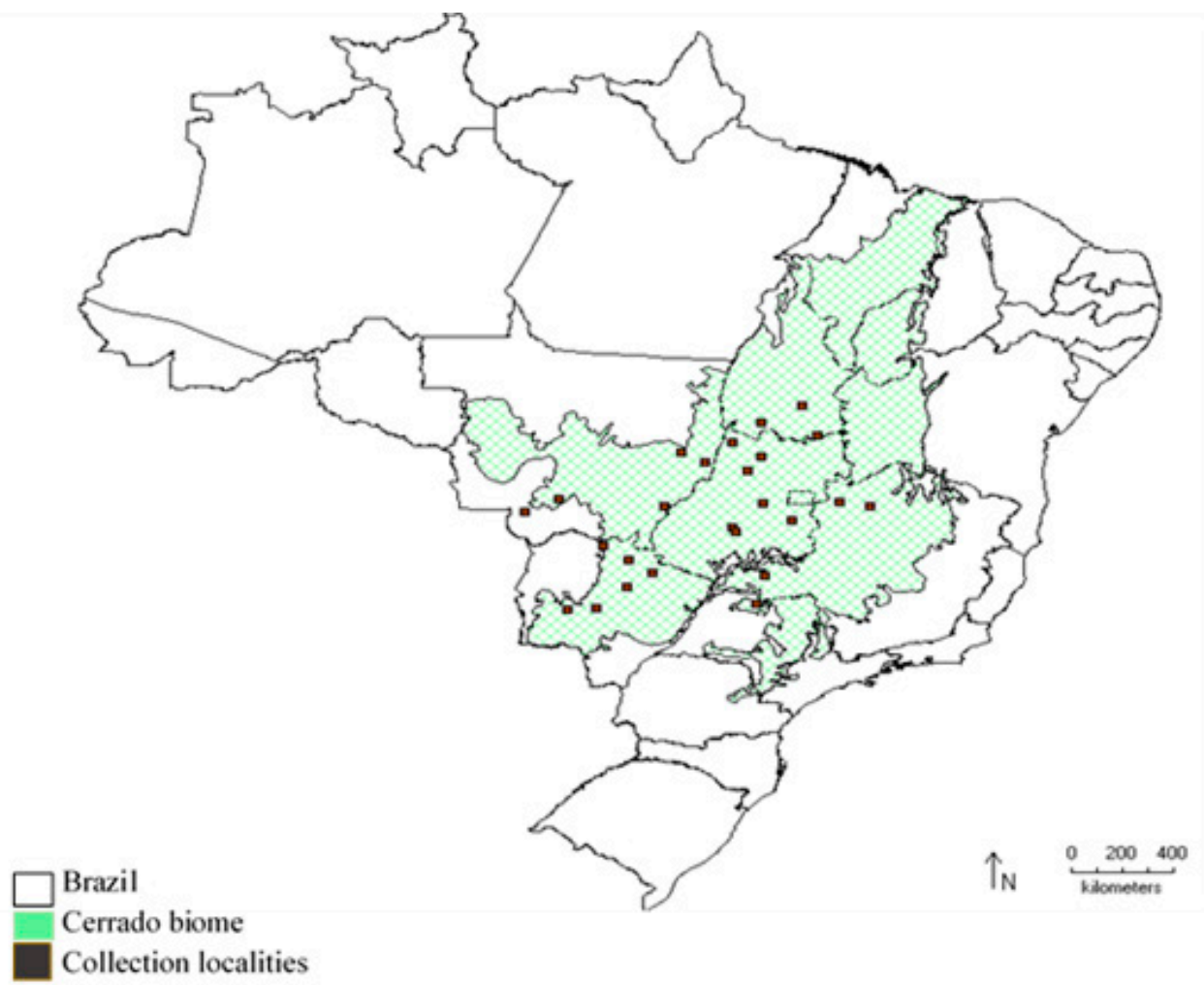

Figure 1. Localities of the collection of the 25 subpopulations of Dipteryx alata Vogel in the Brazilian Cerrado biome.

The evaluated traits were: fruit mass (FM), fruit length (FL), fruit width (FW), fruit thickness (FT), lengthto-width ratio of the fruit (FL/FW), length-to-thickness ratio of the fruit (FL/FT), seed mass (SM), seed length (SL), seed width (SW), seed thickness (ST), length-towidth seed ratio (SL/SW), length-to-thickness seed ratio (SL/ST) and seed yield (SY). The mass characters were obtained using a semi-analytical digital scale and the results expressed in grams (g). Dimension measurements were obtained with a digital pachymeter and expressed in millimeters $(\mathrm{mm})$. Seed yield was obtained by the relation between seed mass and fruit mass $(\mathrm{SY}=\mathrm{SM} / \mathrm{FM})$.

The data were submitted to descriptive statistics and, subsequently, to the analysis of variance based on a hierarchical model with the effect of subpopulations, plants within subpopulations and fruits within plants. The model used was $Y_{i j k}=\mu+S_{i}+p_{j(i)}+f_{k(i j)}$, where:
$Y_{i j k}:$ phenotypic value of fruit (or seed) $k$ from plant $j$ of subpopulation $i$;

$\mu$ : general mean of observed values;

$S_{i}$ : random effect of subpopulation $i, i=1,2, \ldots, S$, $\left.\left[E s_{i}\right)=0, E\left(s_{i}^{2}\right)=\sigma_{s}^{2}\right]$;

$p_{j(i)}$ : random effect of plant $j$ within subpopulation $i, j=1,2, \ldots, m_{i}, \quad\left[E\left(\mathrm{p}_{j(i)}=0, E\left(\mathrm{p}_{j(i)}^{2}\right)=\sigma_{p / s}^{2}\right]\right.$;

$f_{k(i j}$ : random effect of fruit $k$ within plant $j$ of subpopulation $i, k=1,2, \ldots, f_{j},\left[E\left(\mathrm{f}_{k(i j)}=0, E\left(\mathrm{f}_{k(i j)}^{2}\right)=\sigma_{f / p}^{2}\right]\right.$.

In this case, the number of mother plants per subpopulation $\left(m_{i}=6\right)$ and fruits per mother plant $\left(f_{j}=5\right)$ were constant, therefore the data set was balanced. The scheme for the analysis of variance and the expectations of the mean squares (Table 1) were elaborated according to the adopted statistical model. 
Table 1. Scheme of analysis of variance and expectations of the mean squares, according to the hierarchical statistical model, with the effects of subpopulations, plants within subpopulations and fruits or seeds within plants, for physical characters of Dipteryx alata Vogel from 25 subpopulations of the Brazilian Cerrado.

\begin{tabular}{lccl}
\hline \multicolumn{1}{c}{ Sources of Variation } & DF & MS & E(MS) \\
\hline Subpopulations & $\mathrm{S}-1$ & $\mathrm{M}_{1}$ & $\sigma^{2}+5 \sigma^{2}{ }_{m / s}+30 \sigma^{2}$ \\
Plants/Subpopulations & $\mathrm{M}-\mathrm{S}$ & $\mathrm{M}_{2}$ & $\sigma^{2}+5 \sigma_{m / s}^{2}$ \\
Fruits or seeds/Plants & $\mathrm{F}-\mathrm{M}$ & $\mathrm{M}_{3}$ & $\sigma^{2}$ \\
Total & $\mathrm{F}-1$ & & \\
\hline
\end{tabular}

DF: degrees of freedom; MS: mean squares; $\mathrm{E}(\mathrm{MS})$ : expectation for mean squares; S: number of subpopulations ( $\mathrm{S}=25)$; $\mathrm{M}$ : total number of mother plants $(\mathrm{M}=150)$ and $\mathrm{F}$ : total numbers of fruits or seeds $(\mathrm{F}=750)$.

The components of variance associated with the effects of the model and its proportions in relation to the total phenotypic variation were estimated according to the expectations of the ANOVA mean squares as follow: difference among subpopulations $\left(P_{S}\right)$, difference among plants within subpopulations $\left(P_{P / S}\right)$ and difference among fruits or seeds within plants $\left(P_{F / P}\right)$. Using the components of variance, the parameter $P_{S T}$ was also estimated, which measures the quantitative phenotypic divergence among subpopulations. The estimators for the parameters are:

$$
\begin{aligned}
& P_{S}=\frac{\hat{\sigma}_{s}^{2}}{\hat{\sigma}_{s}^{2}+\hat{\sigma}_{p / s}^{2}+\hat{\sigma}_{f / p}^{2}} ; \\
& P_{P / S}=\frac{\hat{\sigma}_{p / s}^{2}}{\hat{\sigma}_{s}^{2}+\hat{\sigma}_{p / s}^{2}+\hat{\sigma}_{f / p}^{2}} ; \\
& P_{F / P}=\frac{\hat{\sigma}_{f / p}^{2}}{\hat{\sigma}_{s}^{2}+\hat{\sigma}_{p / s}^{2}+\hat{\sigma}_{f / p}^{2}} ; \\
& P_{S T}=\frac{\hat{\sigma}_{s}^{2}}{\hat{\sigma}_{s}^{2}+2 \hat{\sigma}_{p / s}^{2}} .
\end{aligned}
$$

The phenotypic correlation coefficients between traits were also estimated, considering the different hierarchical levels. The analyses were performed based on the genetic-statistical procedure of the Genes software (CRUZ, 2013).

\section{Results and discussion}

The descriptive analysis of the 13 evaluated traits, based on the values of the coefficient of phenotypic variation $(\mathrm{CV})$, demonstrated a greater variability for the characters fruit mass (FM), seed mass (SM) and seed yield (SY) and lower for seed width (SW), fruit width (FW) and length-to-width fruit ratio (FL/FW) (Table 2).

The mass values of whole fruit ranged from 9.75 $\mathrm{g}$ to $72.97 \mathrm{~g}$ (Table 2), with an average of $28.13 \mathrm{~g}$. The results found for fruit mass by Sano et al. (1999), Corrêa et al. (2000), Corrêa et al. (2008) are within the range found in the current study. One different case is the lower values found by Melhem (1974), with a range from $10 \mathrm{~g}$ to $28 \mathrm{~g}$, and an average of $18 \mathrm{~g}$. FM presented the highest relative phenotypic variation among the evaluated fruit traits, with a phenotypic coefficient of variation equal to $33.09 \%$ (Table 2). Corrêa et al. (2000) also observed a greater variation for this variable. Subpopulations 11 (Estrela do Norte, GO) and 25 (Cáceres, MT) had the highest means for FM (Table 2). The greater amplitudes of variation found here were expected due to the large geographical area sampled, covering greater environmental variation and, probably, greater genetic variation.

The fruit length (FL) varied from $36.20 \mathrm{~mm}$ to $77.42 \mathrm{~mm}$ with a mean of $52.27 \mathrm{~mm}$ (Table 2). This wide amplitude of variation is according to the study of Corrêa et al. (2000). On the other hand, Silva et al. (1994), Ferreira et al. (1998), and Corrêa et al. (2008) found a smaller amplitude of variation, but within the range of this study. The subpopulations with the highest means for this trait were 11 (Estrela do Norte, GO) and 3 (Pirenópolis, GO) (Table 2). The values of fruit width and fruit thickness (Table 2) are also in accordance with data from the literature (SILVA et al., 1994; FERREIRA et al., 1998; CORRÊA et al., 2000; CORRÊA et al., 2008), with a trend for larger variation intervals, as expected due to the larger sample size. 
Table 2. Means per subpopulation, minimum and maximum values (average per plot) and coefficients of phenotypic variation (CV) of physical traits of fruits and seeds of Dipteryx alata Vogel from 25 subpopulations of the Brazilian Cerrado.

\begin{tabular}{|c|c|c|c|c|c|c|c|c|c|c|c|c|c|}
\hline \multirow{2}{*}{ Subpopulation/Locality } & \multicolumn{13}{|c|}{ Traits } \\
\hline & $\mathbf{F M}$ & FL & FW & FT & FL/FW & FL/FT & SM & SL & SW & ST & SL/SW & SL/ST & SY \\
\hline 1- Cocalinho (MT) & 18.19 & 50.36 & 38.50 & 25.57 & 1.31 & 1.97 & 1.09 & 23.24 & 10.36 & 8.204 & .246 & 2.841 & 0.060 \\
\hline 2- Água Boa (MT) & 32.06 & 54.82 & 42.01 & 30.52 & 1.30 & 1.80 & 1.28 & 25.21 & 10.82 & 8.349 & 2.338 & 3.055 & 0.041 \\
\hline 3- Pirenópolis (GO) & 33.05 & 59.48 & 43.32 & 30.34 & 1.37 & 1.97 & 1.27 & 26.86 & 10.98 & 8.003 & 2.460 & 3.389 & 0.044 \\
\hline 4- Sonora (MS) & 27.90 & 51.42 & 41.62 & 28.25 & 1.24 & 1.82 & 1.52 & 26.38 & 11.05 & 8.752 & 2.398 & 3.052 & 0.054 \\
\hline 5- Alcinópolis (MS) & 26.45 & 52.62 & 37.96 & 28.94 & 1.39 & 1.82 & 1.18 & 24.10 & 10.52 & 8.234 & 2.296 & 2.998 & 0.044 \\
\hline 6- Alvorada (TO) & 27.32 & 49.51 & 40.16 & 30.15 & 1.24 & 1.65 & 1.24 & 24.61 & 9.99 & 8.708 & 2.474 & 2.844 & 0.046 \\
\hline 7- São Miguel do Araguaia (GO) & 27.91 & 51.62 & 38.70 & 29.31 & 1.33 & 1.76 & 1.15 & 24.37 & 10.17 & 8.343 & 2.398 & 2.940 & 0.042 \\
\hline 8- Luziânia (GO) & 28.50 & 54.99 & 43.00 & 28.30 & 1.28 & 1.95 & 1.30 & 25.72 & 11.43 & 8.145 & 2.256 & 3.220 & 0.046 \\
\hline 9- Icém (SP) & 22.77 & 50.73 & 39.24 & 27.83 & 1.29 & 1.82 & 0.97 & 23.54 & 10.13 & 6.956 & 2.343 & 3.536 & 0.041 \\
\hline 10- Monte Alegre de Minas (MG) & 23.23 & 48.01 & 37.39 & 27.31 & 1.28 & 1.75 & 1.07 & 23.31 & 10.98 & 7.558 & 2.123 & 3.117 & 0.047 \\
\hline 11- Estrela do Norte (GO) & 41.15 & 63.85 & 43.01 & 32.60 & 1.48 & 1.96 & 1.47 & 27.97 & 10.38 & 8.516 & 2.709 & 3.306 & 0.037 \\
\hline 12- Santa Terezinha (GO) & 27.92 & 53.57 & 37.95 & 29.48 & 1.41 & 1.82 & 1.30 & 24.54 & 10.60 & 8.597 & 2.323 & 2.877 & 0.047 \\
\hline 13-Arinos (MG) & 25.08 & 49.02 & 38.87 & 28.04 & 1.26 & 1.75 & 1.16 & 23.47 & 10.16 & 8.139 & 2.312 & 2.898 & 0.046 \\
\hline 14- Pintópolis (MG) & 23.52 & 50.05 & 37.31 & 28.48 & 1.34 & 1.76 & 0.97 & 22.77 & 10.04 & 7.842 & 2.276 & 3.057 & 0.041 \\
\hline 15- Paraíso (MS) & 21.58 & 47.03 & 35.42 & 26.49 & 1.33 & 1.78 & 1.09 & 23.52 & 9.83 & 8.178 & 2.425 & 2.913 & 0.052 \\
\hline 16- Terenos (MS) & 26.04 & 48.92 & 38.34 & 28.60 & 1.28 & 1.72 & 1.09 & 23.79 & 10.62 & 7.950 & 2.279 & 3.036 & 0.042 \\
\hline 17- Camapuã (MS) & 28.75 & 48.47 & 39.26 & 28.88 & 1.23 & 1.68 & 1.11 & 24.43 & 10.30 & 7.716 & 2.384 & 3.189 & 0.040 \\
\hline 18- Indiara (GO) & 36.89 & 56.74 & 44.10 & 31.72 & 1.29 & 1.79 & 1.38 & 26.77 & 11.26 & 8.181 & 2.383 & 3.284 & 0.038 \\
\hline 19- Barra do Garças (MT) & 31.58 & 54.61 & 39.71 & 32.18 & 1.38 & 1.71 & 1.39 & 26.44 & 10.36 & 8.890 & 2.564 & 3.017 & 0.044 \\
\hline 20- Várzea Grande (MT) & 29.93 & 48.63 & 39.97 & 31.02 & 1.21 & 1.57 & 1.19 & 23.30 & 10.65 & 8.432 & 2.193 & 2.779 & 0.041 \\
\hline 21- Jandaia (GO) & 34.62 & 57.20 & 41.71 & 31.49 & 1.37 & 1.82 & 1.32 & 26.67 & 11.03 & 8.326 & 2.427 & 3.228 & 0.038 \\
\hline 22- Natividade (TO) & 20.37 & 48.36 & 36.23 & 25.77 & 1.34 & 1.94 & 1.11 & 23.77 & 10.01 & 8.509 & 2.382 & 2.806 & 0.057 \\
\hline 23-Arraias (TO) & 20.60 & 48.76 & 35.14 & 26.04 & 1.39 & 1.92 & 1.00 & 23.12 & 10.17 & 7.802 & 2.282 & 3.016 & 0.051 \\
\hline 24- Aquidauana (MS) & 27.59 & 51.02 & 39.86 & 29.33 & 1.28 & 1.74 & 1.24 & 25.04 & 10.70 & 8.365 & 2.346 & 3.004 & 0.045 \\
\hline 25-Cárceres (MT) & 40.34 & 56.89 & 45.69 & 32.63 & 1.25 & 1.75 & 1.60 & 28.02 & 11.18 & 8.902 & 2.512 & 3.181 & 0.040 \\
\hline Mean & 28.13 & 52.27 & 39.78 & 29.17 & 1.32 & 1.80 & 1.22 & 24.84 & 10.55 & 8.218 & 2.365 & 3.065 & 0.045 \\
\hline Minimum (plot basis) & 9.750 & 36.20 & 29.81 & 15.96 & 1.09 & 1.31 & 0.23 & 15.56 & 5.360 & 2.640 & 1.170 & 2.070 & 0.007 \\
\hline Maximum (plot basis) & 72.97 & 77.42 & 52.48 & 40.62 & 1.68 & 2.88 & 2.39 & 33.09 & 19.84 & 11.30 & 3.510 & 5.890 & 0.098 \\
\hline CV \% & 33.09 & 12.46 & 10.51 & 12.14 & 7.964 & 11.11 & 25.76 & 11.65 & 10.35 & 12.49 & 11.41 & 15.95 & 24.87 \\
\hline
\end{tabular}

FM: Fruit mass (g); FL: Fruit length (mm); FW: Fruit width (mm); FT: Fruit thickness (mm); FL/FW: Length-to-width fruit ratio (mm) and FL/ FT: Length-to-thickness fruit ratio (mm); SM: Total seed mass (g); SL: Seed length (mm), SW: Seed width (mm); ST: Seed thickness (mm), SL/SW: Length-to-width seed ratio (mm); SL/ST: Length-to-thickness seed ratio (mm) and SY: Seed yield (SY $=\mathrm{SM} / \mathrm{FM})$. 
Table 3. Analysis of variance of 13 physical traits of fruits and seeds of Dipteryx alata Vogel from 25 subpopulations of the Brazilian Cerrado.

\begin{tabular}{|c|c|c|c|c|c|c|c|c|c|c|c|c|c|c|}
\hline \multirow{2}{*}{ Sources of Variation } & \multirow{2}{*}{ GL } & \multicolumn{12}{|c|}{ Mean Squares } & \multirow[b]{2}{*}{ SY } \\
\hline & & FM & FL & FW & FT & FL/FW & FL/FT & SM & SL & SW & ST & SL/SW & SL/ST & \\
\hline Subpopulations & 24 & $105.4^{* *}$ & $521.0 * *$ & $221.1 * *$ & $128.8^{* *}$ & $0.128 * *$ & $0.326^{*}$ & $0.832 * *$ & $75.09 * *$ & $6.034^{\mathrm{ns}}$ & $5.843^{\mathrm{ns}}$ & $0.447^{\mathrm{ns}}$ & $1.131^{\mathrm{ns}}$ & $10.410 * *$ \\
\hline Plants/ Subpopulations & 125 & $251.8^{* *}$ & $120.3^{* *}$ & $51.02 * *$ & $42.38^{* *}$ & $0.029 * *$ & $0.144^{* *}$ & $0.294 * *$ & $27.02 * *$ & * $3.812 * *$ & $3.406^{* *}$ & $* 0.246 * *$ & $0.819 * *$ & $3.900 * *$ \\
\hline Fruits or seeds/ Plants & 600 & 13.63 & 7.064 & 2.378 & 1.689 & 0.002 & 0.006 & 0.028 & 1.841 & 0.455 & 0.372 & 0.021 & 0.082 & 0.300 \\
\hline$P_{S}(\%)$ & & 30.37 & 31.01 & 31.89 & 22.67 & 30.84 & 15.29 & 18.09 & 18.90 & 6.17 & 7.66 & 9.22 & 4.34 & 17.54 \\
\hline$P_{M / S}(\%)$ & & 54.14 & 52.58 & 54.73 & 64.04 & 50.47 & 69.58 & 53.67 & 59.39 & 55.93 & 57.24 & 61.90 & 61.47 & 58.21 \\
\hline$P_{F / P}(\%)$ & & 15.49 & 16.40 & 13.38 & 13.29 & 18.69 & 15.13 & 28.24 & 21.71 & 37.90 & 35.09 & 28.89 & 34.20 & 24.25 \\
\hline$P_{S T}$ & & 0.219 & 0.228 & 0.226 & 0.150 & 0.234 & 0.099 & 0.144 & 0.137 & 0.052 & 0.063 & 0.069 & 0.034 & 0.131 \\
\hline
\end{tabular}

FM: Fruit mass (g); FL: Fruit length (mm); FW: Fruit width (mm); FT: Fruit thickness (mm); FL/FW: Length-to-width fruit ratio (mm) and FL/FT: Length-to-thickness fruit ratio (mm); SM: Total seed mass (g); SL: Seed length (mm), SW: Seed width (mm); ST: Seed thickness (mm), SL/SW: Lengthto-width seed ratio (mm); SL/ST: Length-to-thickness seed ratio $(\mathrm{mm})$ and SY: Seed yield $(\mathrm{SY}=\mathrm{SM} / \mathrm{FM}) .{ }^{\text {ns: }}$ not significant; * and $* *$ Significant at $5 \%$ and $1 \%$ probability levels by $t$ test, respectively. $P_{S}:$ proportion of the total variance due to the difference among subpopulations; $P_{M / S}:$ proportion of the total variance due to the difference among plants within subpopulations; $P_{F / P}$ : proportion of the total variance due to the difference among fruits or seeds within plants; $P_{S T}$ : quantitative phenotypic differentiation among subpopulations.

The length-to-width fruit ratio (FL/FW) and the length-to-thickness fruit ratio (FL/FT) presented means of 1.31 and 1.80 , respectively, characterizing ovate and flat fruits. The variable FL/FW presented the lowest coefficient of variation among the evaluated traits $(7.96 \%)$, much smaller than the highest value, which was $33.09 \%$ for FM. The variation interval for this trait was relatively small, which demonstrates a similarity in the shape of the fruit among subpopulations.

The physical characterization of the seeds presented the following averages (Table 2): $1.22 \mathrm{~g}$ of mass (SM), $24.84 \mathrm{~mm}$ in length (SL), $10.55 \mathrm{~mm}$ in width (SW) and $8.21 \mathrm{~mm}$ in thickness (ST). SM trait presented a greater amplitude of variation than those reported by Sano et al. $(1999 ; 2010 b)$ and with a similar mean to that found by Corrêa et al. (2008). Here the mean of SM was slightly lower than that found by Silva et al. (1994), which was $1.50 \mathrm{~g}$. These differences regarding to other studies can be explained by the differences in sampling procedures and extension. The amplitudes of variation observed for the fruit and seed traits are, generally, higher than the values of the referred studies, probably due to the greater representativeness of the sample of this study. The mean values of the traits associated with the seed dimensions (SL, SW and ST) and their relation characterize long seeds with oval cross-section. Among the sampled subpopulations, 11 (Estrela do Norte, GO) presented the highest mean values for the fruit traits, with the highest averages for fruit mass (FM) and fruit length (FL). Also noteworthy are the subpopulations 25 (Cáceres, MT), 18 (Indiara, GO) and 3 (Pirenópolis, GO), which had a good average performance. The fruits of these subpopulations are heavier and larger, making them more attractive to the fresh market.

The subpopulations highlighted in their average performance for seed variables were 25 (Cáceres, MT) and 11 (Estrela do Norte, GO), followed by subpopulations 19 (Barra do Garças, MT), 21 (Jandaia, GO) and 4 (Sonora,
MS). Notoriously, the two subpopulations with the highest average value for fruit characters were the same for seed characters, showing a positive association between these variables. These subpopulations presented seeds well developed morphologically and with a higher weight. It should be noted that the greatest economic appeal of D. alata is in the nutritional value of its seed, which has high levels of proteins and lipids, high concentration of unsaturated fatty acids and some minerals (VERA et al., 2009). Its use in food has been carried out in different ways, including sweets, jellies, liqueurs, ice cream, pies, chocolates, cereal bars, flour, oil, among others. However, the product with the greatest economic appeal is roasted nuts, which reach high values in the specialized market. Current demand is usually supplied by community associations and family farmers (CANDIL et al., 2007), with a still incipient production chain. However, some large-scale planting initiatives already exist, requiring the development of cultivation techniques and selected populations. As an example, there are plantings on the farms such as, Grupo Tropical, in São Luiz do Norte, GO; Santa Julieta Bio, in Santa Cruz da Conceição, SP and Agropecuária Kehler, in Brejinho de Nazaré, TO. There are also several farmers and extractivists associations in different regions of the Cerrado biome that explore baru tree products in addition to other native fruit species.

The seed yield (SY) measured by the SM/FM ratio showed a mean value of $4.50 \%$, therefore $95.50 \%$ of the fruit mass, on average, corresponds to the endocarp and pulp mass. This low yield, combined with the difficulty in extracting the seed from the fruit, constitute a major challenge for the use of baru nut. Subpopulations 1 (Cocalinho, MT), 4 (Sonora, MS), 15 (Paraíso, MS), 22 (Natividade, TO) and 23 (Arraias, TO) had the highest values for seed yield, despite the low mean for fruit and seed mass. An exception is subpopulation 4 (Sonora, MS), which presented adequate values for seed traits combined 
with a high value of SY, even with low values for FM.

These results demonstrate that there is a wide phenotypic variation among the localities for some of the traits under study, mainly for the mass variables, which is relevant for the purposes of conservation and genetic improvement. The great variation in the results, when compared to other authors studies, highlights the statement by Sano and Simon (2008), that the production of baru fruits is, in general, extremely variable among the years. These authors also mention that baru fruits have larger dimensions in the years of smaller production and vice versa. Thus, the dimensions found in the subpopulations of this study, as they were sampled in one year of greater production, may increase in years of smaller production.

The hierarchical analysis of variance showed the existence of significant variation between subpopulations for all characters with the exception of seed width (SW), seed thickness (ST) and the ratio of seed length (SL) with these two variables (Table 3), which shows some uniformity among subpopulations for the shape of the seed. Assuming that part of the significant variation is determined by genetic causes, these results reinforce the possibility of selecting provenances with desirable characteristics, including seed mass and length. The variation among plants within subpopulations was highly significant for all characters. Considering only the mass variables, the partition of the source of variation among plants by each subpopulation (data not shown) showed significant variation for fruit mass (FM) within all subpopulations and for seed mass (SM) in 23 out of 25 subpopulations.. This shows the feasibility of selecting superior mother plants from different provenances.

Of all the variation observed, most are due to the phenotypic variation among plants within subpopulations $\left(P_{P / S}\right)$, as can be seen in the estimated values of the variation proportions for each trait (Table 3), ranging from 50.47 \% for the ratio between length and width of the fruit $(\mathrm{FL} / \mathrm{FW})$ to $69.58 \%$ for the ratio between length and thickness of the fruit $(\mathrm{FL} / \mathrm{FT})$. This greater proportion of variation among plants within subpopulations in relation to the variation among subpopulations is expected for allogamous species and agree with results already reported for D. alata (SANO et al., 1996, 1999; CORREA et al., 2000) and other fruit species from the Cerrado biome (SILVA et al., 2001; VERA et al., 2005; TRINDADE and CHAVES, 2005; GANGA et al., 2009; MOURA et al., 2013; NOVAES et al., 2018). The phenotypic variation among subpopulations and among matrices within subpopulations is influenced by uncontrolled environmental factors, such as soil, climate, anthropic interferences, plant age, competition, and also by the genetic difference among individuals.

For the variation among fruits within plants, there is a difference in proportions of fruit and seed traits (Table 3). For all fruit traits, the proportion of variation within plants $\left(P_{F / P}\right)$ was below $20 \%$ and was lower than the proportion among subpopulations, showing a certain uniformity of fruits per plant. For seed traits, this proportion varied from $24.25 \%$ to $37.90 \%$, intermediate values between the proportions among subpopulations and among plants within subpopulations. Assuming that the heritability of the traits is similar among subpopulations and among plants, the data of components proportions of variance allow to predict greater efficiency in the selection among progenies in comparison to the selection among provenances.

The $P_{S T}$ values for the fruit traits ranged from 0.099 to 0.234 . With the exception of the FL/FT ratio, the values were greater than 0.150 . The seed characters ranged from 0.034 to 0.137 . Thus, the estimated $P_{S T}$ values for the fruit traits were higher than the $P_{S T}$ estimates for the seed traits. The $P_{S T}$ parameter is a measure of the quantitative phenotypic differentiation among the subpopulations and is a surrogate to the $Q_{S T}$ parameter that measures the quantitative genetic differentiation among the subpopulations (BROMMER, 2011). These parameters can be used as an indicator of the selection forces that shaped the current structure of population variability. To infer on evolutionary processes, the $Q_{S T}$ parameter must be compared with the non-adaptive variation that can be assessed by neutral molecular markers (WHITLOCK and GUILLAUME, 2009; NOVAES et al., 2018). The difference in $P_{S T}$ values among fruit and seed traits allow the hypothesis of different evolutionary forces acting on these traits, which must be evaluated in a specific study.

The significant variability among the subpopulations allied to the great amplitude of variation found for most of the evaluated traits of the baru tree emphasizes that they behave differently among the collection localities. In this way, subpopulations, or collection sites with better performance, for traits of interest in the market can be recommended. Based on the means of the variables for fruit and seed characters, subpopulations 25 (Cáceres, MT) and 11 (Estrela do Norte, GO) stand out, although with seed yield below average. The population 4 (Sonora, MS) is noteworthy for being the second with the highest seed mass (SM) and the third in seed yield, due to having a below average fruit mass. In addition to the average performance, the indication of the best localities for collection also depends on the internal variability of each subpopulation. Based on the seed mass (SM) variable, which has the highest economic value, the subpopulation 4 (Sonora, MS) mentioned above stands out for internal variability. Subpopulation 11 is among the five with the greatest variability. Subpopulation 25 (Cáceres) has intermediate variability. The variability of each subpopulation in this study was estimated based on a sample of only six plants, so it must be taken with caution.

The coefficients of phenotypic correlations among the variables at different hierarchical levels, among subpopulations, among mother plants within subpopulations and among fruits within plants, showed a positive and significant correlation between most pairs 
of the evaluated traits (Table 4). The correlation in the level of fruits within plants is only due to environmental effects (non-genetic), in the other levels the genetic and environmental effects are confounded. In these cases, when the phenotypic correlation coefficient is of high magnitude in absolute value, it means that both the genetic correlation and the environmental correlation must also be of high magnitude. When the phenotypic correlation is of low magnitude, it can happen that its components are also of low magnitude or that they present opposite signs. The correlation among fruits within plants, therefore, can give an indication of the sign of environmental correlation, allowing certain inferences about the other levels.

Table 4. Estimates of phenotypic correlation coefficients at different hierarchical levels, for the traits of fruits and seeds of Dipteryx alata Vogel from 25 subpopulations of the Brazilian Cerrado.

\begin{tabular}{|c|c|c|c|c|}
\hline Trait pairs & Total & Subpopulation & $\begin{array}{c}\text { Plants/ } \\
\text { subponulations }\end{array}$ & Fruits/Plants \\
\hline FM : FL & $0.836^{* *}$ & $0.823 * *$ & $0.858^{* *}$ & $0.767 * *$ \\
\hline FM : FW & $0.846^{* *}$ & $0.851 * *$ & $0.867 * *$ & $0.739 * *$ \\
\hline FM : FT & $0.878 * *$ & $0.967 * *$ & $0.869 * *$ & $0.765^{* *}$ \\
\hline FM : SM & $0.710 * *$ & $0.867 * *$ & $0.708 * *$ & $0.576^{* *}$ \\
\hline FM : SL & $0.743 * *$ & $0.975 * *$ & $0.707 * *$ & $0.571 * *$ \\
\hline FM : SW & $0.407 * *$ & $0.748 * *$ & $0.407 * *$ & $0.313 * *$ \\
\hline FM : ST & $0.331 * *$ & $0.547 * *$ & $0.320 * *$ & $0.292 *$ \\
\hline FM : SY & $-0.565 * *$ & $-0.774 * *$ & $-0.609 * *$ & $-0.314 * *$ \\
\hline FL : FW & $0.765^{* *}$ & $0.767 * *$ & $0.781^{* *}$ & $0.684 * *$ \\
\hline FL : FT & $0.662 * *$ & $0.759 * *$ & $0.645^{* *}$ & $0.573 * *$ \\
\hline FL : SM & $0.647 * *$ & $0.721 * *$ & $0.678^{* *}$ & $0.507 * *$ \\
\hline FL : SL & $0.813 * *$ & $0.891 * *$ & $0.842^{* *}$ & $0.631 * *$ \\
\hline FL : SW & $0.375 * *$ & $0.665 * *$ & $0.392 * *$ & $0.254^{*}$ \\
\hline FL : ST & $0.185 * *$ & $0.431 * *$ & $0.138^{\mathrm{ns}}$ & $0.192^{\text {ns }}$ \\
\hline FL : SY & $-0.388 * *$ & $-0.515 * *$ & $-0.437 * *$ & $-0.187^{\text {ns }}$ \\
\hline FW : FT & $0.726 * *$ & $0.761 * *$ & $0.746^{* *}$ & $0.564 * *$ \\
\hline FW : SM & $0.680 * *$ & $0.845 * *$ & $0.702 * *$ & $0.449 * *$ \\
\hline FW : SL & $0.707 * *$ & $0.941 * *$ & $0.681 * *$ & $0.484 * *$ \\
\hline FW : SW & $0.514 * *$ & $0.973 * *$ & $0538^{* *}$ & $0.299 * *$ \\
\hline FW : ST & $0.247 * *$ & $0.401 * *$ & $0.251^{*}$ & $0.183^{\mathrm{ns}}$ \\
\hline FW : SY & $-0.421 * *$ & $-0.532 * *$ & $-0.471 * *$ & $-0.237^{*}$ \\
\hline FT : SM & $0.586^{* *}$ & $0.789^{* *}$ & $0.582 * *$ & $0.400 * *$ \\
\hline FT : SL & $0.558 * *$ & $0.907 * *$ & $0.486^{* *}$ & $0.409 * *$ \\
\hline FT : SW & $0.329 * *$ & $0.535^{* *}$ & $0.347 * *$ & $0.228 *$ \\
\hline FT : ST & $0.376 * *$ & $0.531 * *$ & $0.397 * *$ & $0.273 * *$ \\
\hline FT : SY & $-0.611 * *$ & $-0.841 * *$ & $-0.665^{* *}$ & $-0.317 * *$ \\
\hline SM : SL & $0.778 * *$ & $0.989 * *$ & $0.751 * *$ & $0.682 * *$ \\
\hline SM : SW & $0.626^{* *}$ & $0.594 * *$ & $0.664 * *$ & $0.593 * *$ \\
\hline SM : ST & $0.685^{* *}$ & $0.837 * *$ & $0.662 * *$ & $0.709 * *$ \\
\hline SM : SY & $0.104^{\mathrm{ns}}$ & $-0.432 * *$ & $0.112^{\mathrm{ns}}$ & $0.586^{* *}$ \\
\hline SL : SW & $0.463 * *$ & $0.787 * *$ & $0.445^{* *}$ & $0.416^{* *}$ \\
\hline SL : ST & $0.252 * *$ & $0.837 * *$ & $0.140^{\text {ns }}$ & $0.290 * *$ \\
\hline SL : SY & $-0.154 * *$ & $-0.537 * *$ & $-0.173^{\text {ns }}$ & $0.244 *$ \\
\hline SW : ST & $0.291^{* *}$ & $0.710^{* *}$ & $0.294 * *$ & $0.368^{* *}$ \\
\hline SW : SY & $0.140 *$ & $-0.702 * *$ & $0.203^{*}$ & $0.408^{* *}$ \\
\hline ST : SY & $0.288^{* *}$ & $-0.044^{\text {ns }}$ & $0.277 * *$ & $0.609 * *$ \\
\hline
\end{tabular}

FM: Fruit mass (g); FL: Fruit length (mm); FW: Fruit width (mm); FT: Fruit thickness (mm); FL/FW: Length-to-width fruit ratio (mm) and FL/ FT: Length-to-thickness fruit ratio (mm); SM: Total seed mass (g); SL: Seed length (mm), SW: Seed width (mm); ST: Seed thickness (mm), SL/SW: Length-to-width seed ratio (mm); SL/ST: Length-to-thickness seed ratio (mm) and SY: Seed yield (SY = SM/FM). ${ }^{\text {ns: }}$ not significant; $*$ and $* *$ Significant at $5 \%$ and $1 \%$ probability levels by $t$ test, respectively. 
Based on the total phenotypic correlation and among means of subpopulations, the total fruit mass (FM) trait was highly correlated with the other dimensional characters of fruits and seeds, showing a negative correlation with SY, which was expected (Table 4). Corrêa et al. (2000) observed the same trend of correlation between the fruit mass and the other characters, as in this study. The positive and high correlations observed between the variables such as, fruit length (FL) with seed length (SL) and SL with seed mass (SM) should be highlighted, as these variables are of interest in the market. In the analysis of correlation among plants within subpopulations, as well as fruits within matrices, the trait FM was also highly correlated with the other characters of fruits and the same negative correlation with the variable SY. The high and positive correlation estimates are confirmed between the characters of FL and SL, SM and SL, as well as observed in the correlation among subpopulations.

The negative correlation among all the variables of fruits with seed yield (SY), although expected by the mathematical relation of SY with fruit mass, represents a difficulty for selecting plants with larger seeds and with high yield. On the other hand, the close relation of these fruit traits with the mass and dimensions of the seed, allows the field selection of plants with larger fruits resulting in seeds with superior characteristics, since it would be impractical to evaluate the seeds traits in the field. The best alternative for using baru genetic resources could then be to select plants with larger fruits and seeds, even with less yield, and direct efforts to use the pulp and even the mesocarp as by-products.

\section{Conclusions}

The results of this study allow us to affirm that there is a high phenotypic variability for most of the physical traits of D. alata fruits and seeds, in all tested hierarchical levels, except among subpopulations for the traits such as width and thickness of the seed, length-to-width and length-to-thickness seed ratio. The largest proportion of phenotypic variability is among mother plants within subpopulations. The phenotypic divergence among subpopulations measured by the $P_{S T}$ parameter is greater for fruit traits than for seed traits. In order to support a conservation and breeding program for the species, it is recommended to sample a large number of subpopulations to ensure an adequate representativeness of the observed variability. The size of the fruit (mass and dimensions) is highly correlated with the size of the seed and can be used for mass selection of mother plants in the field in a collection program for purposes of genetic improvement. Based on the general performance of the subpopulations, the priority collection localities that can be recommended for a breeding program are subpopulations 4 (Sonora, MS), 11 (Estrela do Norte, GO) and 25 (Cáceres, MT). It would be advisable to expand the collection areas in these regions, focusing on traits of interest to the market.

\section{References}

ALMEIDA, S.P. Cerrado: aproveitamento alimentar. Planaltina: Embrapa-CPAC, 1998. 188p.

BOTEZELLI L.; DAVIDE, A.C.; MALAVASI, M.M. Características dos frutos e sementes de quatro procedências de Dipteryx alata Vogel (Baru). Cerne, Uberlândia, v.6, n.1, p.9-19, 2000.

BRASIL. Ministério da Agricultura, Pecuária e Abastecimento. Instrução Normativa $n^{\circ} 49$, de 26 de setembro de 2018. Estabelece em todo o território nacional a complementação dos padrões de identidade e qualidade de suco e polpa de fruta. Brasília: Diário Oficial da União, 27 de setembro de 2018.

BROMMER, J.E. Whither PST? The approximation of QST by PST in evolutionary and conservation biology. Journal of Evolutionary Biology, Oxford, v.24, n.6, p.1160-1168, 2011.

CANDIL, R.F.M.; ARRUDA, E.J. de; ARAKAKI, A.H. Tonkabean (Dipteryx alata Vog.), Local Development and the Biological Sustainability in the Andalucia Settling, Nioaque/MS. Revista Internacional de Desenvolvimento Local, Campo Grande, v.8, n.1, p.75-80, 2007.

COLLEVATTI, R.G.; TELLES, M.P.C.; NABOUT, J.C.; CHAVES, L.J.; SOARES, T.N. Demographic history and the low genetic diversity in Dipteryx alata (Fabaceae) from Brazil Neotropical savannas. Heredity, Oxford, v.111, n.2, p.97-105, 2013.

CORREAA, G. de C.; NAVES, R.V.; ROCHA, M.R. da; ZICA, L.F. Caracterização física de frutos de baru (Dipteryx alata Vog.) em três populações nos Cerrados do Estado de Goiás. Pesquisa Agropecuária Tropical, Goiânia, v.30, n.2, p.5-11, 2000.

CORRÊA, G.C.; NAVES, R.V.; ROCHA, M.R.; CHAVES, L.J.; BORGES, J.D. Determinações físicas em frutos e sementes de baru (Dipteryx alata Vog.), cajuzinho (Anacardium othonianum Rizz.) e pequi (Caryocar brasiliense Camb.), visando melhoramento genético. Bioscience Journal, Uberlândia, v.24, n.4, p.42-47, 2008. 
CRUZ, C.D. GENES - a software package for analysis in experimental statistics and quantitative genetics. Acta Scientiarum, Maringá, v.35, n.3, p.271-276, 2013.

DINIZ, J.D.A.; CERDAN, C. Produtos da sociobiodiversidade e cadeias curtas: aproximação socioespacial para uma valorização cultural e econômica. In: GAZOLLA, M.; SCHNEIDER, S. Cadeias curtas e redes agroalimentares alternativas. Negócios e mercados da agricultura familiar. Porto Alegre: Ed. Da UFRGS, 2017. p.261-282. (Série de Estudos Rurais).

FERREIRA, M.B. Plantas portadoras de substâncias medicamentosas, de uso popular, nos cerrados de Minas Gerais. Informe Agropecuário, Belo Horizonte, v.6, n.61, p.19-23, 1980.

FERREIRA, R.A.; BOTELHO, S.A.; DAVID A.C.; MALAVASI, M.M. Caracterização morfológica de fruto, semente, plântula e muda de Dipteryx alata Vogel - baru (leguminosae papilionoideae). Cerne, Uberlândia, v.4, n.1, p.73-87, 1998.

GANGA, R.M.D.; CHAVES, L.C.; NAVES, R.V. Parâmetros genéticos em progênies de Hancornia speciosa Gomes do Cerrado. Scientia Forestalis, Piracicaba, v.37, n.84, p.395-404, 2009.

GUIMARÃES, R.A.; MIRANDA, K.M.C.; MOTA, E.E.S.; CHAVES, L.J.; TELLES, M.P.C.; SOARES, T.N. Assessing genetic diversity and population structure in a Dipteryx alata germplasm collection utilizing microsatellite markers. Crop Breeding and Applied Biotechnology, Viçosa, MG, v.19, n.3, p.329-336, 2019a.

GUIMARÃES, R.A.; MIRANDA, K.M.C.; CHAVES, L.J.; NAVES, R. V.; TELLES, M.P.C.; SOARES, T.N. Mating system and pollen dispersal in Dipteryx alata Vogel (Leguminosae): comparing in situ and ex situ conditions. Tree Genetics \& Genomes, Berlin, v.15, n.28, 2019b.

KAGEYAMA, P.Y.; CUNHA, G.C.; BARRETO, K.D.; GANDARA, F.B.; CAMARGO, F.R.A.; SEBBENN, A.M. Diversidade e autocorrelação genética espacial em populações de Ocotea odorífera (Lauraceae). Scientia Forestalis, Piracicaba, v.1, n.64, p.108-119, 2003.

KLINK, C.A.; MACHADO, R.B. A conservação do cerrado brasileiro. Megadiversidade, Belo Horizonte, v.1, n.1, p.148-155, 2005.
LORENZI, H. Árvores brasileiras: manual de identificação e cultivo de plantas arbóreas nativas do Brasil. Nova Odessa: Plantarum, 1998. 352p.

MELHEM, T.S. Morfologia e anatomia da unidade de dispersão de Dipteryx alata Vog. (LeguminosaeLotoideae). Hoehnea, São Paulo, v.4, p.13-33, 1974.

MENDONÇA, R.C.; FELFILI, J.M.; WALTER, B.M.T.; SILVA JÚNIOR, M.C.; REZENDE, A.V.; FILGUEIRAS, T.S.; NOGUEIRA, P.E. \& FAGG, C.W. 2008. Flora vascular do cerrado: Chechlist com 12.356 espécies. In: SANO, S.M.; ALMEIDA, S.P.; RIBEIRO, J.R. (Ed.). Cerrado: ecologia e flora. Planaltina: Embrapa-CPAC, Planaltina, 2008. p.417.

MESSIAS, L.S.; CAMARGO, R. A.L. A chamada pública como alternativa à licitação: seu uso na aquisição de produtos da agricultura familiar para a alimentação escolar. In: SEMINÁRIO INTERNACIONAL DE PESQUISA EM POLÍTICAS PÚBLICAS E DESENVOLVIMENTO SOCIAL, 2., 2016, São Paulo. Anais [...] Franca: UNESP, 2016.

MING L.C.; HIDALGO, A.F.; SILVA, M.A.S.; SILVA, S.M.P.; CHAVES, F.C.M. Espécies Brasileiras com potencial alimentar: uso atual e desafios. Botucatu: Faculdade de Ciências Agronômicas/UNESP, 2000. 237p.

MITTERMEIER, R.A.; TURNER, W.R.; LARSEN, F.W.; BROOKS, T.M.; GASCON, C. 2011. Global biodiversity conservation: the critical role of hotspots. In: ZACHOS, F.E.; HABEL, J.C.(Ed.), Biodiversity hotspots. London: Springer Publishers, 2011. p.3-22.

MOURA, N.F.; CHAVES, L.J.; NAVES, R.V. Caracterização física de frutos de pequizeiro (Caryocar brasiliense Camb.) do cerrado. Revista Árvore, Viçosa, MG, v.37, n.5, p.905-912, 2013.

MYERS, N.; MITTERMEIER, R.A.; MITTERMEIER, C.G.; FONSECA, G.A.B.; KENT, J. Biodiversity hotspots for conservation priorities. Nature, London, v.403, n.1, p.853-858, 2000.

NOVAES, C.R.D.B.; MOTA, E.E.S.; NOVAES, E.; TELLES, M.P.C.; CHAVES, L.J. Structure of the phenotypic variability of fruit and seed traits in natural populations of Eugenia dysenterica DC. (Myrtaceae). Revista Brasileira de Fruticultura, Jaboticabal, v.40, n.3, e-843, 2018. 
PAIVA, F.F.A.; LEITE, L.A.S.; PESSOA, P.F.A.P.; SOUZANETO, J.; SÁ, F.T.; SILVA NETO, R.M.; FERNANDES, A.R. Processamento de castanha de caju. In: SILVA, C.A.B. da; FERNANDES, A.R. (Ed.). Projetos de empreendimentos agroindustriais: produtos de origem vegetal. Viçosa: Ed. da UFV, 2003. v.2, p.171-214.

PEREIRA, M.E.; PASQUALETO, A. Desenvolvimento Sustentável com ênfase em frutíferas do Cerrado. Revista Estudos PUC-GO, Goiânia, v.38, n.2, p.333-363, 2011.

SANO, S.M.; VIVALDI, L.J. Produção de baru (Dipteryx alata Vog.) no seu habitat. In: SIMPÓSIO INTERNACIONAL SOBRE ECOSSISTEMAS FLORESTAIS/FOREST, 4., Belo Horizonte, 1996. Resumos [...] Belo Horizonte: Biosfera. 1996. p.217-18.

SANO, S.M.; VIVALDI, L.J.; SPEHAR, C.R. Diversidade morfológica de frutos e sementes de baru (Dipteryx alata Vog.). Pesquisa Agropecuária Brasileira, Brasília, DF, v.34, n.4, p.513-518, 1999.

SANO, S.M.; RIBEIRO, J.F.; BRITO, M.A. de. Baru: biologia e uso. Planaltina, DF: Embrapa Cerrados, 2004. 52 p. (Documentos, 116).

SANO, S.M.; SIMON, M.F .Produtividade de baru (Dipteryx alata Vog.) em ambientes modificados, durante 10 anos. Desafios e estratégias para o equilíbrio entre sociedade, agronegócio e recursos naturais. In: SIMPÓSIO NACIONAL CERRADO, 9.; SIMPÓSIO INTERNACIONAL SAVANAS TROPICAIS, 2., 2008, Brasília. Anais [...]. Planaltina, DF: Embrapa Cerrados, 2008. 1 CD-ROM. 1 folder

SANO, E.E.; ROSA, R.; BRITO, J.L.S.; FERREIRA, L.G. Land cover mapping of the tropical savanna region in Brazil. Environmental Monitoring and Assessment, Dordrecht, v.166, p.113-124, 2010a.

SANO, S.M.; BRITO, M.A.; RIBEIRO, J.F. Baru. In: VIEIRA, R. F.; AGOSTINI-COSTA, T. S.; SILVA, D. B.; FERREIRA, F. R.; SANO. S. M. (Ed.) Frutas nativas da região Centro-Oeste do Brasil. Brasília: Embrapa Recursos Genéticos e Biotecnologia, 2010b. 322p.

SILVA, J.A.; SILVA, D.B.; JUNQUEIRA, N.T.V.; ANDRADE, L.R.M. Frutas nativas dos cerrados. Brasília: CPAC-Embrapa, 1994. 166p.
SILVA, R.M.; CHAVES, L.J.; NAVES, R.V. Caracterização de frutos e árvores de cagaita (Eugenia dysenterica DC.) no sudeste do estado de Goiás, Brasil. Revista Brasileira de Fruticultura, Jaboticabal, v.23, n.2, p.330-334, 2001.

SOARES, T.N.; CHAVES L.J.; TELLES M.P.C.; DINIZFILHO J.A.F. Resende LV. Distribuição espacial da variabilidade genética intrapopulacional de Dipteryx alata. Pesquisa Agropecuária Brasileira, Brasília, DF, v.43, n.9, p.1151-1158, 2008.

SOARES, T.N.; DINIZ-FILHO, J.A.F.; NABOUT, J.C.; TELLES, M.P.C.; TERRIBILE, L.C.; CHAVES, L.J. Patterns of genetic variability in central and peripheral populations of Dipteryx alata (Fabaceae) in the Brazilian Cerrado. Plant Systematic and Ecology, Heidelberg, v.301, p.1315-1324, 2015.

TELLES, M.P.C.; DOBROVOLSKI, R.; SOUZA, K.S.; LIMA, J.S.; COLLEVATTI, R.G.; SOARES, T.N.; CHAVES L.J.; DINIZ-FILHO, J.A.F. Disentangling landscape effects on population genetic structure of a Neotropical savana tree. Natureza \& Conservação, Rio de Janeiro, v.12, n. 1, p.65-70, 2014.

TRINDADE, M.G.; CHAVES, L.J. Genetic structure of natural Eugenia dusenterica (Myrtaceae) populations in northeaster Goiás, Brazil, accessed by morphological traits and RAPD markers. Genetics and Molecular Biology, Ribeirão Preto, v.28, n.3, p.407-413, 2005.

VERA, R.; NAVES, R.V.; NASCIMENTO, J.L. do; CHAVES, L.J.; LENDRO, W.M.; SOUZA, E.R.B. de. Caracterização física de frutos do pequizeiro (Caryocar brasiliense Camb.) no Estado de Goiás. Pesquisa Agropecuária Tropical, Goiânia, v.35, p.71-79, 2005.

VERA, R.; SOARES JUNIOR, M.S.; NAVES, R.V.; SOUZA, E.R.B.; FERNANDES, E.P.; CALIARI, M.; LEANDRO, W.M. Características químicas de amêndoas de barueiros (Dipteryx alata Vog.) de ocorrência natural no cerrado do estado de Goiás, Brasil. Revista Brasileira de Fruticultura, Jaboticabal, v.31, n.1, p.112-118, 2009.

WHITLOCK, M.C.; GUILLAUME, F. Testing for spatially divergent selection: comparing $\mathrm{Q}_{\mathrm{ST}}$ to $\mathrm{F}_{\mathrm{ST}}$. Genetics, Austin, v.183, p.1055-1063, 2009. 